\title{
酸触媒下におけるメラミンのホルムアルデヒドによる ヒドロキシメチル化における塩勃果*
}

\author{
佐藤 謙二 $^{* 1} \cdot$ 阿部芳首 ${ }^{* 1} \cdot$ 佐藤 誠 $^{* 1}$
}

（受付 1974 年 2 月 1 日・審查終了 1974 年 6 月 14 日)

\begin{abstract}
要 旨 酸触媒下に扮けるメラミン $(\mathbf{M H})$ のホルムアルデヒド $(\mathbf{F})$ によるヒドロキシメチル化に おける塩勃果を検討した。.この結果ヒドロキシメチル化の全速度定数 $(k)$ は [過塩素酸 $]_{0} /[\mathrm{MH}]_{0}=$ $0.1,0.9$ (モル比)の場合は塩化ナトリウムの添加により影響を受けないが, [過塩素酸 $]_{0} /[\mathrm{MH}]_{0}=5.0$ (モル比)の場合は塩化ナトリウム, 硝酸ナトリウム, 硫酸ナトリウムの添加によるイオン強度 $(\mu)$ の 增加とともに增加し, 塩浱度の小さい場合にはこ5配 $\mathrm{d} \log k / \mathrm{d} \sqrt{ } \bar{\mu} \doteqdot 1$ の直線関係が成立すること が分かった. これらの結果から [過塩素酸 $]_{0} /[\mathrm{MH}]_{0}>1$ に扝ける主反応は共役酸 MH とメチロール カチオン $\left(\stackrel{\mathrm{C}}{\mathrm{C}} \mathrm{H}_{2} \mathrm{OH}\right)$ の反応であることなどが推論された.
\end{abstract}

\section{1 緒言}

酸触媒下におけるメラミン $(\mathbf{M H})$ のホルムアルデヒド (F)によるヒドロキシメチル化に関する研究は少ない。 従来, 岡野ら"1 $\mathrm{pH} 3$ 以上の領域において速度定数が $\mathrm{pH}$ の減少とともに減少することを見いだした。ささらに 佐藤 ${ }^{21}$ は $\mathrm{pH} 1$ までの強酸性領域について検討し, $\mathrm{pH}$ 約 2 ([塩酸 $\left.]_{0} /[\mathrm{MH}]_{0} \doteqdot 1.0\right)$ に極小が存在することを見いだ し, 速度論的考察からこの領域でのヒドロキシメチル化 の機構を説明した。 その数年後, 浦上ら ${ }^{31}$ は酸触媒下の アセトグフナミンのヒドロキシメチル化に批いて, 同様 な極小を認めている. de Jong ら41 は尿素のヒドロキシ メチル化における塩効果に関して，塩化カリウムを用い $\mathrm{pH} 4$ および 7 で検討しているが，塩効果は認められな かったと報告している.

しかるに MH のFによるヒドロキシメチル化におけ る塩効果についてはこれまでに知られていないので，本 報では水溶液中で酸触媒下におけるヒドロキシメチル化 速度に及ぼす塩効果について検討し，さらにこの結果か ら反応機構に考察を加えた。

以下, [ ] は濃度 $(\mathrm{mol} / l),[$ ]0 は初濃度 $(\mathrm{mol} / l)$ を示 した.

\section{2 実験}

\section{1 試料}

MH は市販 1 級品を水より再結晶して用いた，F は

* 本報を「メラミン樹脂に関する研究 第 8 報」とす る

*1 東京理科大学理工学部工業化学科( 278 野田市山 崎東刍山 2641)
市販 1 級パラホルムアルデヒド $150 \mathrm{~g}$ に純水 $150 \mathrm{~g}$ を加 えた後蒸留し, 留出 $\mathrm{F}$ 水溶液を水酸化ナトリウム水溶液 で $\mathrm{pH} 7.0$ に中和して用いた. 塩酸, 過塩素酸 $\left(\mathrm{HClO}_{4}\right)$, 水酸化ナトリウム, 亜硫酸ナトリウム(無水), 塩化ナト リウム, 硝酸ナトリウム(無水), 硫酸ナトリウム(無水) は市販特級品を使用した。

\section{2 反応速度 $R_{0}$ の測定法}

所定温度の恒温槽中で $500 \mathrm{~m} l$ メスフラスコに一定モ ル比になるように $\mathrm{MH}$ と $\mathrm{HClO}_{4}$ を取り, 塩として塩 化ナトリウム,硝酸ナトリウム,または硫酸ナトリウムを 加えた後蒸留水で溶解させて $500 \mathrm{~m} l$ にした。 この水溶 液にあらかじめ恒温槽中で $100 \mathrm{~m} l$ に調製した既知濃度 の $\mathrm{F}$ 水溶液を加之, 加えたときを反応開始時間とし, 以 後一定時間ごとに反応液の一部を取り出し, 亜硫酸ナト リウム法”により末反応 $\mathrm{F}$ を定量した・ $\mathrm{pH}$ はガラス電 極 $\mathrm{pH}$ メータで測定した。な拉本研究の結果は数回の実 験の平均値を示した。

\section{3 結果と考察}

\section{$3.1 k$ の算出および $k$ に及ぼす塩効果}

$\boldsymbol{R}_{0}$ は消費 $\mathrm{F}$ と反応時間の曲線において時間 0 におけ る接線の傾きとして求めた. Fig. 1 はその数例を示し た. 全速度定数 $k$ は得られた $\boldsymbol{R}_{0} と[\mathrm{MH}]_{0}$, および $[\mathrm{F}]_{0}$ を速度式 $\boldsymbol{R}_{0}=k[\mathrm{MH}][\mathrm{F}]^{5 /}$ に代入して算出した. Fig. 2 は $\left[\mathrm{HClO}_{4}\right]_{0} /[\mathrm{MH}]_{0}=0.1$ および 0.9 において塩化ナト リウムを添加した場合の塩効果を示したが，溶液のイオ 強度を $\mu$ とするといずれの場合もこう配 $\mathrm{d} \log k / \mathrm{d} \sqrt{\mu}$ $=0$ の直線となり，塩化ナトリウムの添加は $k$ に影響を 与えないことが分かった。 一方, $\left[\mathrm{HClO}_{4}\right]_{0} /[\mathrm{MH}]_{0}=5.0$ において塩化ナトリウム, 硝酸ナトリウム, 硫酸ナトリ 


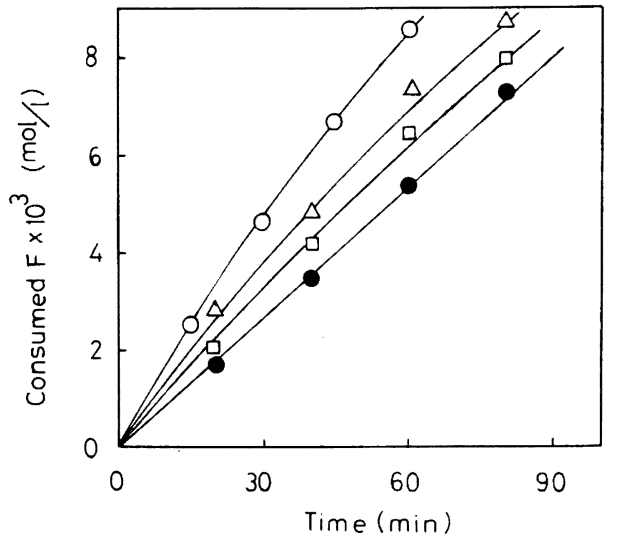

Fig. 1. Relationship between the consumed $\mathbf{F}$ and the reaction time at $50^{\circ} \mathrm{C}$.

$\left[\mathrm{HClO}_{4}\right]_{0} /[\mathrm{MH}]_{0}=5.0 ;[\mathrm{MH}]_{0}, 0.015 \mathrm{~mol} / l ;[\mathrm{F}]_{0}$, $0.300 \mathrm{~mol} / l ; \mathrm{NaCl}$ added $\bigcirc, 0 ; \square, 0.05 \mathrm{~mol} / l$; $\triangle, 0.07 \mathrm{~mol} / l ; \bigcirc, 0.20 \mathrm{~mol} / l$.

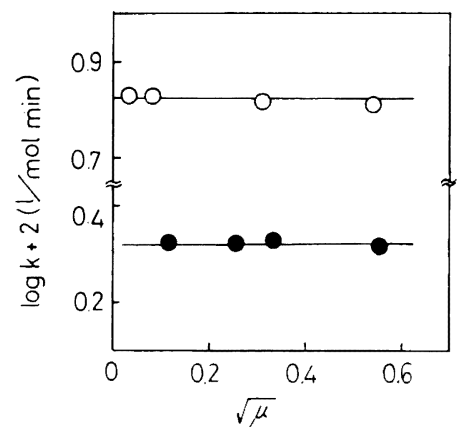

Fig. 2. Relationship between $\log k$ and $\sqrt{\mu}$ at $50^{\circ} \mathrm{C}$ when $\mathrm{NaCl}$ is added.

$[\mathrm{MH}]_{0}, \quad 0.015 \mathrm{~mol} / l ; \quad[\mathrm{F}]_{0}, \quad 0.300 \mathrm{~mol} / l ; \quad \bigcirc$, $\left[\mathrm{HClO}_{4}\right]_{0} /[\mathrm{MH}]_{0}=0.10$ (from left, $\mathrm{NaCl}$ added is $0,0.05,0.10,0.30 \mathrm{~mol} / l$, respectively); $\left[\mathrm{HClO}_{4}\right]_{0} /[\mathrm{MH}]_{0}=0.90$ (from left, $\mathrm{NaCl}$ added is $0,0.05,0.10,0.30 \mathrm{~mol} / l)$.

ウムを添加した場合の塩効果を Table 1 に示してある が，Fig. 3 にはこの表をもとに $\log k \sim \sqrt{\mu}$ の関係を示 した. Fig. 3から明らかなように, $k$ は塩化ナトリウム, 硝酸ナトリウム，または硫酸ナトリウムの添加による $\mu$ の増加とともに增加し, 塩濃度の小さい場合 $(\sqrt{ } \bar{\mu}<$ 0.3）それぞれこ5配 $\mathrm{d} \log k / \mathrm{d} \sqrt{\mu}=0.95,0.88,1.0$ の 直線関係が成立することが分かった。

\section{2 塩効果とヒトロキシメチル化機構}

前述のように $k$ は $\left[\mathrm{HClO}_{4}\right]_{0} /[\mathrm{MH}]_{0}=0.1,0.9$ の際に は塩の添加により影響を受けないが, $\left[\mathrm{HClO}_{4}\right]_{0} /[\mathrm{MH}]_{0}=$ 5.0 の強酸性では塩濃度の増加とともに増加しており, この事実はこれらの領域でヒドロキシャチル化の反応
Table 1. Salt effects in the hydroxymethylation of melamine with formaldehyde at $50^{\circ} \mathrm{C}$.

\begin{tabular}{cllll}
\hline \multirow{2}{*}{ Salt } & $(\mathrm{mol} / l)$ & $\begin{array}{c}{[\mathrm{F}]_{0}} \\
(\mathrm{~mol} / l)\end{array}$ & $\mathrm{pH}$ & $\begin{array}{c}k \\
(l / \mathrm{mol} \mathrm{min})\end{array}$ \\
\hline & 0 & 0.296 & 1.26 & $1.96 \times 10^{-2}$ \\
$\mathrm{NaCl}$ & 0.02 & 0.296 & 1.28 & $2.12 \times 10^{-2}$ \\
& 0.05 & 0.296 & 1.25 & $2.52 \times 10^{-2}$ \\
& 0.10 & 0.296 & 1.25 & $2.82 \times 10^{-2}$ \\
& 0.20 & 0.296 & 1.26 & $3.38 \times 10^{-2}$ \\
\hline & 0 & 0.297 & 1.28 & $2.02 \times 10^{-2}$ \\
& 0.01 & 0.295 & 1.28 & $1.99 \times 10^{-2}$ \\
$\mathrm{NaNO}_{3}$ & 0.05 & 0.297 & 1.28 & $2.29 \times 10^{-2}$ \\
& 0.10 & 0.296 & 1.28 & $2.56 \times 10^{-2}$ \\
& 0.20 & 0.297 & 1.28 & $3.05 \times 10^{-2}$ \\
\hline \multirow{2}{*}{$\mathrm{Na}_{2} \mathrm{SO}_{4}$} & 0 & 0.292 & 1.29 & $1.95 \times 10^{-2}$ \\
& 0.005 & 0.296 & 1.30 & $2.11 \times 10^{-2}$
\end{tabular}

$\left[\mathrm{HClO}_{4}\right]_{0} /[\mathrm{MH}]_{0}=5.0 ;[\mathrm{MH}]_{0}, 0.015 \mathrm{~mol} / l$.

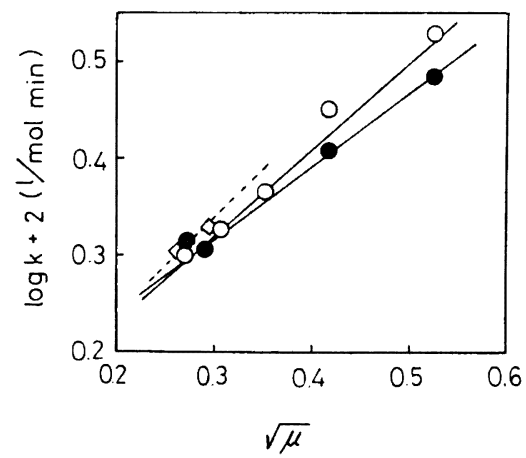

Fig. 3. Relationship between $\log k$ and $\sqrt{\mu}$ at $50^{\circ} \mathrm{C}$ when various salts are added.

- $\mathrm{NaNO}_{3} ; \bigcirc, \mathrm{NaCl} ; \diamond, \mathrm{Na}_{2} \mathrm{SO}_{4}$ (their slopes are $0.88,0.95$, and 1.00 , respectively).

種, すなわち反応機構が異なることを示唆するので6, 以下のように考察を加えた.

MH と F は酸性で (1), (2), (3) 式の平衡状態で存在 ᄂ,

$$
\begin{aligned}
& \mathrm{MH}+\mathrm{H}^{+} \stackrel{K_{1}}{\rightleftarrows} \mathrm{MH}_{2}{ }^{+} \\
& \mathrm{HCHO}+\mathrm{H}^{+} \stackrel{K_{2}}{\rightleftarrows} \stackrel{+}{\rightleftarrows} \mathrm{H}_{2} \mathrm{OH} \\
& \mathrm{HCHO}+\mathrm{H}_{2} \mathrm{O} \stackrel{K_{3}}{\rightleftarrows} \mathrm{CH}_{2}(\mathrm{OH})_{2}
\end{aligned}
$$

$$
\left(\begin{array}{l}
\mathrm{K}_{1}, \mathrm{~K}_{2}, \mathrm{~K}_{3}: \text { 平衡定数 } \\
\mathrm{MH}_{2}{ }^{+}: \text {共役酸 } \mathrm{MH} \\
\mathrm{CH}_{2}(\mathrm{OH})_{2}: \text { メチレングリ } \\
{ }_{+}^{+} \mathrm{C}_{2} \mathrm{OH}: \text { メチロールカチオン }
\end{array}\right)
$$

このためヒドロキシメチル化には Table 2 に示したよ5 
酸触媒下におけるメラミンのホルムアルデヒドによるヒドロキシメチル化に拄ける塩効果

Table 2. Elementary reactions of hydroxymethylation.

\begin{tabular}{lcc}
\hline & $\mathrm{MH}$ & $\mathrm{MH}_{2}{ }^{+}$ \\
\hline $\mathrm{HCHO}$ & $k_{1}$ & $k_{4}$ \\
$\mathrm{CH}_{2}(\mathrm{OH})_{2}$ & $k_{2}$ & $k_{5}$ \\
$+\mathrm{CH}_{2} \mathrm{OH}$ & $k_{3}$ & $k_{6}$ \\
\hline
\end{tabular}

$k_{1}-k_{6}$, the rate constant of the respective elementary reaction.

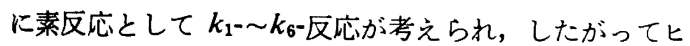
ドロキシメチル化速度 $(\boldsymbol{R})$ は (4) 式で示される.このよ

$\boldsymbol{R}=k_{1}[\mathrm{MH}][\mathrm{HCHO}]+k_{2}[\mathrm{MH}]\left[\mathrm{CH}_{2}(\mathrm{OH})_{2}\right]$ $+k_{3}[\mathrm{MH}]\left[\stackrel{+}{\mathrm{C}} \mathrm{H}_{2} \mathrm{OH}\right]+k_{4}\left[\mathrm{MH}_{2}{ }^{+}\right][\mathrm{HCHO}]$ $+k_{5}\left[\mathrm{MH}_{2}{ }^{+}\right]\left[\mathrm{CH}_{2}(\mathrm{OH})_{2}\right]+k_{6}\left[\mathrm{MH}_{2}{ }^{+}\right]\left[\stackrel{+}{\mathrm{C}} \mathrm{H}_{2} \mathrm{OH}\right]$

5にヒドロキシメチル化は複合反応であり，かつ2次の 速度式が成立することから（4）式の反応が律速段階と考 えられるので，(4) 式の併発反応においてそれぞれ $k_{1-}$, $k_{2^{-}}, k_{3^{-}}, k_{4^{-}}, k_{5^{-}}, k_{6}$-反応のいずれかが主反応と仮定した 場合， $k$ と $\mu$ の関係について理論的に考察を加えた.

3.2.1 $k_{6}$-反応が主反応, かつ律速段階と考えた場合

$$
\begin{aligned}
& \boldsymbol{R}=\frac{k^{\prime} f_{\mathrm{MH}_{2}}+f_{\mathrm{CH}_{2} \mathrm{OH}}^{+}}{f_{\mathrm{X}^{\neq}}}\left[\mathrm{MH}_{2}+\right]\left[\stackrel{+}{\mathrm{C}} \mathrm{H}_{2} \mathrm{OH}\right] \\
& =\frac{k^{\prime} \boldsymbol{K}_{1} \boldsymbol{K}_{2} f_{\mathrm{MH}} f_{\mathrm{HCHO}} f_{\mathrm{H}^{+}}^{2}\left[\mathrm{H}^{+}\right]^{2}}{f_{\boldsymbol{X}^{\prime}}}[\mathrm{MH}][\mathrm{HCHO}]
\end{aligned}
$$

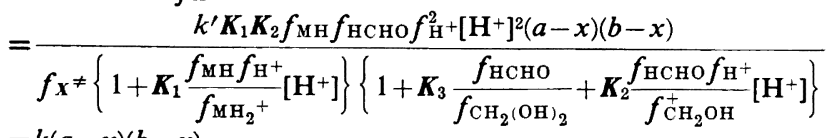

$$
\begin{aligned}
& =k(a-x)(b-x) \\
& k=\frac{k^{\prime} K_{1} K_{2} f_{\mathrm{MH}} f_{\mathrm{HCHO}} f_{\mathrm{H}^{+}}^{2}\left[\mathrm{H}^{+}\right]^{2}}{f_{\mathrm{X}^{\prime}}\left\{1+K_{1} \frac{f_{\mathrm{MH} f_{\mathrm{H}^{+}}}}{f_{\mathrm{MH}_{2}}{ }^{+}}\left[\mathrm{H}^{+}\right]\right\}\left\{1+K_{3} \frac{f_{\mathrm{HCHO}}}{f_{\mathrm{CH}_{2}(\mathrm{OH})_{2}}}+K_{2} \frac{f_{\mathrm{HCHO}} f_{\mathrm{H}^{+}}}{f_{\mathrm{CH}_{2}}^{+} \mathrm{OH}}\left[\mathrm{H}^{+}\right]\right\}} \\
& k_{0}=\frac{k^{\prime} K_{1} K_{2}\left[\mathrm{H}^{+}\right]_{0}{ }^{2}}{\left\{1+K_{1}\left[\mathrm{H}^{+}\right]_{0}\right\}\left\{1+K_{3}+K_{2}\left[\mathrm{H}^{+}\right]_{0}\right\}} \\
& \left(\mathrm{H}_{0}{ }^{+} \text {：塩を添加しない場合の } \mathrm{H}^{+}\right) \\
& k=k_{0}-f_{\mathrm{MH}} f_{\mathrm{HCHO}} f_{\mathrm{H}}^{2}\left[\mathrm{H}^{+}\right]^{2}\left\{1+\boldsymbol{K}_{1}\left[\mathrm{H}^{+}\right]_{0}\right\}\left\{1+\boldsymbol{K}_{3}+\boldsymbol{K}_{2}\left[\mathrm{H}^{+}\right]_{0}\right\} \\
& f_{X^{\prime}} \neq\left[\mathrm{H}^{+}\right]_{0}^{2}\left\{1+K_{1} \frac{f_{\mathrm{MH}} f_{\mathrm{H}^{+}}}{f_{\mathrm{MH}_{2}}{ }^{+}}\left[\mathrm{H}^{+}\right]\right\}\left\{1+K_{3} \frac{f_{\mathrm{HCHO}}}{f_{\mathrm{CH}_{2}(\mathrm{OH})_{2}}}+K_{2} \frac{f_{\mathrm{HCHO}} f_{\mathrm{H}^{+}}}{f_{\mathrm{CH}_{2} \mathrm{OH}}^{+}}\left[\mathrm{H}^{+}\right]\right\} \\
& =k_{0} \frac{f_{\mathrm{MH}} f_{\mathrm{HCHO}} f_{\mathrm{H}^{+}}^{2}}{f_{\mathrm{X}^{\neq}}} \\
& {[\mathrm{MH}]+\left[\mathrm{MH}_{2}^{+}\right]=a-x} \\
& \left.[\mathrm{HCHO}]+\left[\mathrm{CH}_{2}(\mathrm{OH})_{2}\right]+\left[\stackrel{+}{\mathrm{C}} \mathrm{H}_{2} \mathrm{OH}\right]=b-x\right\} \\
& {[\mathrm{MH}]=\frac{a-x}{1+K_{1} \frac{f_{\mathrm{MH}} f_{\mathrm{H}^{+}}}{f_{\mathrm{MH}_{2}}{ }^{+}}\left[\mathrm{H}^{+}\right]}} \\
& {[\mathrm{HCHO}]=\frac{b-x}{1+K_{3} \frac{f_{\mathrm{HCHO}}}{f_{\mathrm{CH}_{2}(\mathrm{OH})_{2}}}+K_{2} \frac{f_{\mathrm{HCHO} \mathrm{H}^{+}}}{f_{\mathrm{CH}_{2} \mathrm{OH}}^{+}}\left[\mathrm{H}^{+}\right]}}
\end{aligned}
$$

\section{の “複合反応” の塩効果}

$k_{6}$-反応は $X^{\neq}$を活性複合体とすると (5) 式で示される のでこの際の速度は（7) 式で与えられ，(6) 式を用いれ ば $(8)$ 式に導かれる. $[\mathrm{MH}]_{0},[\mathrm{~F}]_{0}$ をそれぞれ $a(\mathrm{~mol} / l)$, $b(\mathrm{~mol} / l)$ とし, かつある時間後の $\mathrm{F}$ の消費量を $x(\mathrm{~mol} /$ l) とすると, (15) 式の関係が成立するので (16) 式の関 係が与えられる. (8) 式に (16) 式を代入すれば (9) 式と なり（9）と(10) 式との対比ょり(11) 式が得られる. 塩 を添加しない場合の $k$ を $k_{0}$ とし，この際の活量係数を 1 と仮定すれば, $k_{0}$ は (12) 式で示されるので, (11) と (12) 式か $5, k$ と $k_{0}$ の関倸式として (13) 式が成立す

る. 塩濃度が小さい場合 Debye-Hückel の

$$
\begin{aligned}
& \mathrm{MH}_{2}{ }^{+}+\stackrel{+}{\mathrm{C}} \mathrm{H}_{2} \mathrm{OH} \rightleftarrows X^{\neq} \longrightarrow \text { product } \\
& \boldsymbol{K}_{1}=\frac{\left[\mathrm{MH}_{2}{ }^{+}\right] f_{\mathrm{MH}_{2}{ }^{+}}}{[\mathrm{MH}]\left[\mathrm{H}^{+}\right] f_{\mathrm{MH}} f_{\mathrm{H}^{+}}} \\
& K_{2}=\frac{\left[\stackrel{+}{\mathrm{C}} \mathrm{H}_{2} \mathrm{OH}\right] f_{\mathrm{CH}_{2} \mathrm{OH}}^{+}}{[\mathrm{HCHO}]\left[\mathrm{H}^{+}\right] f_{\mathrm{HCHO}} f_{\mathrm{H}^{+}}} \\
& K_{3}=\frac{\left[\mathrm{CH}_{2}(\mathrm{OH})_{2}\right] f_{\mathrm{CH}_{2}(\mathrm{OH})_{2}}}{[\mathrm{HCHO}] f_{\mathrm{HCHO}}}
\end{aligned}
$$




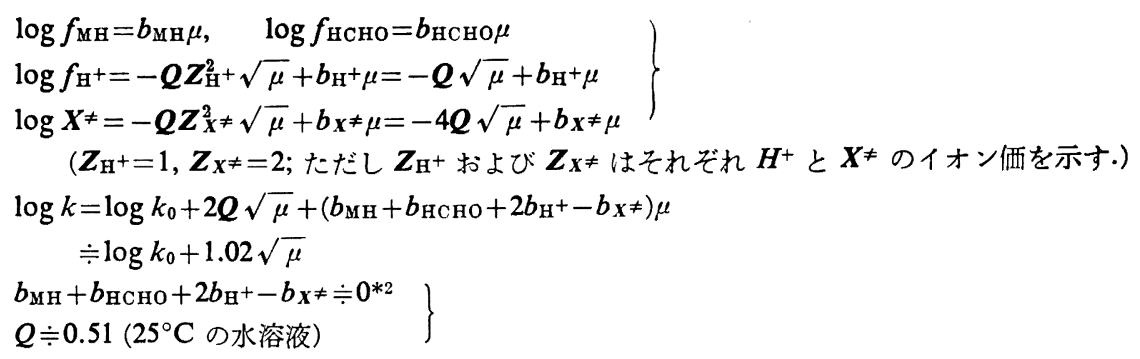

理論 $\left(\log f=-\boldsymbol{Q} \boldsymbol{Z}^{2} \sqrt{\mu}\right)$ が成立すると考えると, (13) 式において $f_{\mathrm{MH}} f_{\mathrm{H}^{+}} / f_{\mathrm{MH}_{2}}+=1, f_{\mathrm{HCHO}} / f_{\mathrm{CH}_{2}(\mathrm{OH})_{2}}=1, f_{\mathrm{HCHO}} f_{\mathrm{H}^{+}}+$

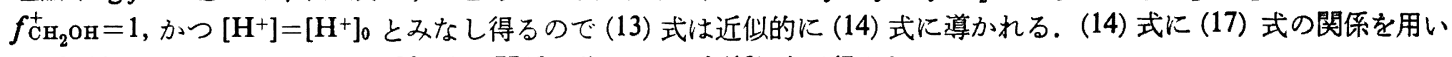
れば(18) 式が得られ，これに(20) 式の関係を代入すれば(19) 式が得られる.

\section{$3.2 .2 k_{1}-, k_{2}-, k_{3^{-}}, \boldsymbol{k}_{4^{-}}, \boldsymbol{k}_{5}$-反応のいずれかが主反応, かつ律速段階と考えた際の複合反応の塩勃果}

この場合 3.2.1 と同様の考察から， $k_{1}$ - $k_{5}$-反応のいずれにおいても次に述べるよらに $k$ と $\mu$ の関係式として (26) 式 が得られた。したがってこれらの反応のいずれも $k$ は $\mu$ に関保なく $\mathrm{d} \log k / \mathrm{d} \sqrt{\mu}=0$ に導かれる.

(i) $\boldsymbol{k}_{1}$-反応

$$
\begin{aligned}
& \mathrm{MH}+\mathrm{HCHO} \rightleftarrows X^{\ddagger} \longrightarrow \text { product } \\
& R=\frac{k^{\prime} f_{\mathrm{MH}} f_{\mathrm{HCHO}}}{f_{X^{\neq}}}[\mathrm{MH}][\mathrm{HCHO}]
\end{aligned}
$$

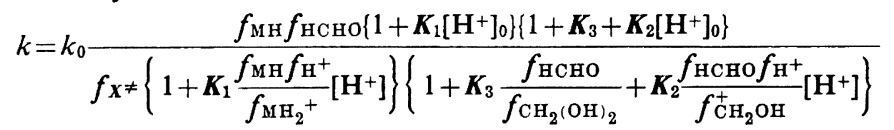

$$
\begin{aligned}
& =k_{0} \frac{f_{\mathrm{MH}} f_{\mathrm{HCHO}}}{f_{X^{\neq}}} \\
& \log k=\log k_{0}+\left(b_{\mathrm{MH}}+b_{\mathrm{HCHO}}-b_{X} \neq\right) \mu \\
& \doteqdot \log k_{0} \quad\left(b_{\mathrm{MH}}+b_{\mathrm{HCHO}}-b_{\mathrm{X}} \neq \doteqdot 0\right)
\end{aligned}
$$

$k_{2}$-反応の場合も同様にして (26) 式に導かれる.

(ii) $\boldsymbol{k}_{3}$-反応

$$
\mathrm{MH}+\stackrel{+}{\mathrm{C}} \mathrm{H}_{2} \mathrm{OH} \rightleftarrows X^{\neq} \longrightarrow \text { product }
$$

$\boldsymbol{R}=\frac{k^{\prime} f_{\mathrm{MH}} f_{\mathrm{CH}}^{+} \mathrm{OH}}{f_{X^{\ddagger}}}[\mathrm{MH}]\left[\stackrel{+}{\mathrm{C}} \mathrm{H}_{2} \mathrm{OH}\right]$

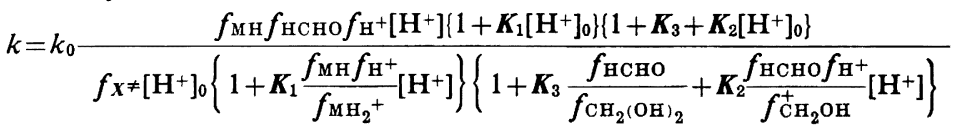

$$
\begin{aligned}
& =k_{0} \frac{f_{\mathrm{MH}} f_{\mathrm{HCHO}} f_{\mathrm{H}^{+}}}{f_{\mathbf{X}^{\neq}}} \\
& \doteqdot \log k_{0}
\end{aligned}
$$

(iii) $\boldsymbol{k}_{4}$-反応

$$
\begin{aligned}
& \mathrm{MH}_{2}{ }^{+}+\mathrm{HCHO} \rightleftarrows X^{\neq} \longrightarrow \text { product } \\
& \boldsymbol{R}=\frac{k^{\prime} f_{\mathrm{MH}_{2}}+f_{\mathrm{HCHO}}}{f_{X} \neq}\left[\mathrm{MH}_{2}{ }^{+}\right][\mathrm{HCHO}] \\
& k=k_{0} \frac{f_{\mathrm{MH}} f_{\mathrm{HCHO}} f_{\mathrm{H}^{+}}\left[\mathrm{H}^{+}\right]\left\{1+K_{1}\left[\mathrm{H}^{+}\right]_{0}\right\}\left\{1+K_{3}+K_{2}\left[\mathrm{H}^{+}\right]_{0}\right\}}{f_{\mathbf{X}^{*}}\left[\mathrm{H}^{+}\right]_{0}\left\{1+K_{1} \frac{f_{\mathrm{MH} f_{\mathrm{H}^{+}}}}{f_{\mathrm{MH}_{2}{ }^{+}}}\left[\mathrm{H}^{+}\right]\right\}\left\{1+\boldsymbol{K}_{3} \frac{f_{\mathrm{HCHO}}}{f_{\mathrm{CH}_{2}(\mathrm{OH})_{2}}}+K_{2} \frac{f_{\mathrm{HCHO}} f_{\mathrm{H}^{+}}}{f_{\mathrm{CH}_{2} \mathrm{OH}}^{+}}\left[\mathrm{H}^{+}\right]\right\}}
\end{aligned}
$$

*2 各種反応の塩勃果において, $\sqrt{\mu}<0.3$ の際に $\log k=\log k_{0}+2 Q Z_{A} Z_{B}\left(Z_{A}, Z_{B}\right.$ ： 反応物のイオン価）の関㐿が 成立することが塞験的に確かめられている7!.このことはこの際にこれらの反応において (20) 式に相当するb 項 がほぼ０であることを示している。 
酸触媒下におけるメラミンのホルムアルデヒドによるヒドロキシメチル化における塩勃果

$$
\begin{aligned}
&=k_{0} \frac{f_{\mathrm{MH}} f_{\mathrm{HCHO}} f_{\mathrm{H}^{+}}}{f_{X^{\neq}}} \\
& \begin{aligned}
\log k & =\log k_{0}+\left(b_{\mathrm{MH}}+b_{\mathrm{HCHO}}+b_{\mathrm{H}^{+}}-b_{X} \neq\right) \mu \\
& \doteqdot \log k_{0}
\end{aligned}
\end{aligned}
$$

$k_{5}$-反応の場合も同様にして (26) 式に導かれる.

\subsection{3 ヒトロキシメチル化機模}

3.1 に述べた実験結果と 3.2.1 および 3.2.2 に述べた理論とを対比することにより以下のようにヒドロキシメチル化 機構に考察を加えた。

$\left[\mathrm{HClO}_{4}\right]_{0} /[\mathrm{MH}]_{0}=5.0$ の強酸性における塩努果では $\mathrm{d} \log k / \mathrm{d} \sqrt{\mu} \doteqdot 0.9 \sim 1.0$ の実測値が得られたが，もしも主反応 が 3.2.2 に述べた $k_{1^{-}}, k_{2^{-}}, k_{3^{-}}, k_{4^{-}}, k_{5^{-}}$反応のいずれか，またはそれらの併発反応と仮定すれば, このいずれの際も $\mathrm{d} \log k / \mathrm{d} \sqrt{\mu}=0$ なので央験結果を説明し得ない，しかるに，もしも 3.2.1 に述べた $k_{6}$-反応，すなわち $\mathrm{MH}_{2}{ }^{+} \varepsilon$ $\stackrel{+}{\mathrm{C}} \mathrm{H}_{2} \mathrm{OH}$ の反応と仮定すれば, $\mathrm{d} \log k / \mathrm{d} \sqrt{\mu}=1$ なので実験結果と一致し, したがって, この際の主反応は $k_{6}$-反応と 推論される.ささら佐藤 ${ }^{21}$ は速度論的研究から [塩酸 $\mathrm{J}_{0} /[\mathrm{MH}]_{0}>1$ の強酸性領域の主反応を $k_{6}$-反応と述べているので この結果とも一致する.

さらに $k_{6}$-反応を (33) 式に示した. (33) 式の $\stackrel{++}{\mathrm{M}} \mathrm{H}_{2} \mathrm{CH}_{2} \mathrm{OH}$ は 3.2.1 に述べた活性複合体 $X^{\ddagger}$ である.この際 ${ }_{\mathrm{M}} \mathrm{M}_{2} \mathrm{CH}_{2} \mathrm{OH}$ はその構造から明らかなよらに共鳴安定化していると考えられるので, 活性複合体と考えるよりも Jonge(1), Ugelstad (8) が酸触媒下における尿素, 安息香酸了ミドの F によるとドロキシメチル化において述べている機 構と同じょうに中間体と考え， $k_{6}$ 反反応を (33-1) および (33-2) 式の二つの素反応に分けて考えてみよ5。この場合, (33-1) 式を律速段階と考えると, その活性複合体のイオン価は $Z_{X} \neq=2$ とみなし得るので, 3.2 .1 と同様に塩効果は

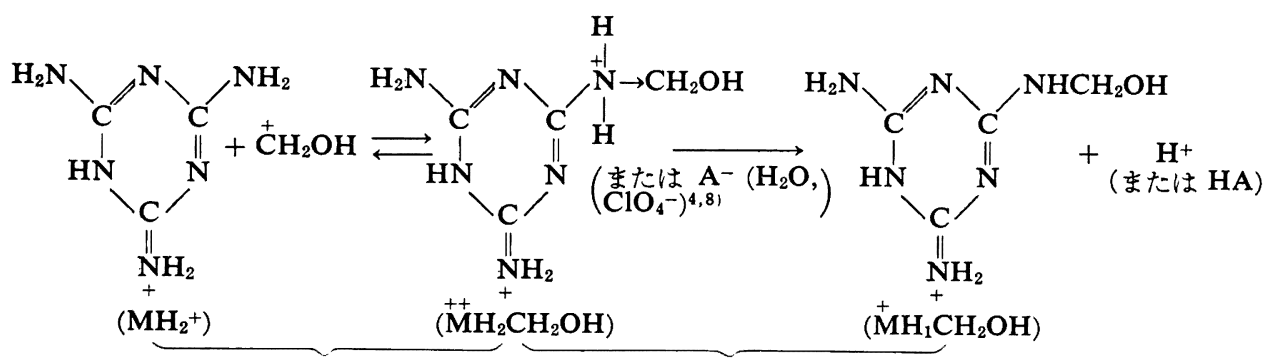

(33-1)

$(33-2)$

理論的に $\mathrm{d} \log k / \mathrm{d} \sqrt{\mu}=1$ であり実測結果と一致する.このため(33-1) 式が律速段階と推定される.もしも(33-2) 式 を律速段階と仮定すれば（34） (39) 式に示すよ5に理論的に負の塩効果を示すので (33-2) 式を律速段階と考之るの は適当ではないであろう(この際 Jonge ${ }^{4)}, \mathrm{Ugelstad}^{81}$ が述べていると同様に $\mathrm{MH}_{2} \mathrm{CH}_{2} \mathrm{OH}$ に水または $\mathrm{ClO}_{4^{-}}$が反応 すると考えても負の塩効果を示す).

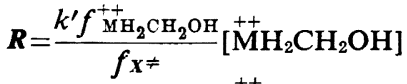

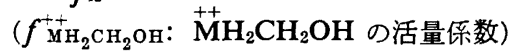

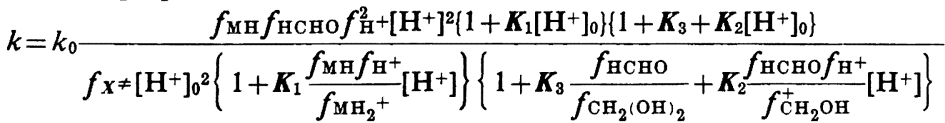

$$
\begin{aligned}
& =k_{0} \frac{f_{\mathrm{MH}} f_{\mathrm{HCHO}} f_{\mathrm{H}^{+}}^{2}}{f_{\mathbf{X}^{\neq}}} \\
& \left.\begin{array}{rl}
\log f_{X} & =-Q Z_{X} \neq \sqrt{\mu}+b_{X} \neq \mu \\
& =-0.51 \sqrt{\mu}+b_{X} \neq \mu \quad\left(\because Z_{X} \neq=1\right)
\end{array}\right\} \\
& \log k=\log k_{0}-0.51 \sqrt{\mu}+\left(b_{\mathrm{MH}}+b_{\mathrm{HCHO}}+2 b_{\mathrm{H}^{+}}-b_{\mathrm{X}} \neq\right) \mu \\
& \doteqdot \log k_{0}-0.51 \sqrt{\mu}
\end{aligned}
$$

次に, $\left[\mathrm{HClO}_{4}\right]_{0} /[\mathrm{MH}]_{0}=0.9,0.1$ の弱酸性の塩効果は $\mathrm{d} \log k / \mathrm{d} \sqrt{\mu}=0$ なので, 3.2 .2 の場合に一致する. したがっ てこの領域での主反応は $k_{1^{-}}, k_{2^{-}}, k_{3^{-}}, k_{4^{-}}, k_{5^{-}}$反応のいずれか，またはこれらの併発反応と考えられる. 


\section{佐藤・阿部・佐藤}

佐藤" ${ }^{21}$ は $0<[\text { 塩酸 }]_{0} /[\mathrm{MH}]_{0}<1$ の弱酸性領域での主反応 を $k_{1^{-}}, k_{2^{-}}, k_{3^{-}}, k_{4^{-}}, k_{5^{-}}$反応の併発反応と述べているので この結果とも一致する.

付記 本研究に協力された木村 健氏に深く感謝する.

\section{文献}

1) M. Okano, Y. Ogata: J. Amer. Chem. Soc., 74, 5728 (1952).

2) 佐藤萐二: 1963 年 4 月, 日本化学会第 16 年会 で報告; 工化誌，72, 1911，1915 (1969).

3）浦上 忠, 大岩 正芳：1966 年 9 月, 第 16 回熱 硬化性樹脂講演討論会で報告; 工化誌，71，591
(1968).

4) J. I. de Jong, J. de Jonge: Rec. Trav. Chim., 71, 643 (1952).

5) 佐藤謙二, 阿部芳首, 木村 健, 佐藤 誠：第 23回熱硬化性樹脂講演討論会, 講演要旨集 Pp. 1 4, (1973).

6) A. Frost, R. G. Pearson: "Kinetics and Mechanism," John Wiley \& Sons, Inc., New York (1953) p. 142, 150.

7) K.J. Laidler: "Chemical Kinetics," McGrawHill, London (1965) p. 219.

8) J. Ugelstad, J. de Jonge: Rec. Trav. Chim., 76, 919 (1957). 